\title{
Edaphic Relationships Among Tree Species in the Kapur (Dryobalanops aromatica Gaertn.f.) Forests of Peninsular Malaysia
}

\author{
${ }^{1}$ Nik Norafida, N.A., ${ }^{1,2}$ Nizam, M.S., ${ }^{1}$ Wan Juliana, W.A. \& ${ }^{3}$ Faezah, P.
}

${ }^{1}$ School of Environmental and Natural Resource Sciences, Faculty of Science and Technology, Universiti Kebangsaan Malaysia, 43600 UKM Bangi, Selangor, Malaysia.

${ }^{2}$ Institute of Climate Change, Universiti Kebangsaan Malaysia, 43600 UKM Bangi, Selangor, Malaysia.

${ }^{3}$ Faculty of Applied Sciences, Universiti Teknologi MARA, 40450 Shah Alam, Selangor, Malaysia.

Correspondence Author: Nizam, M.S., School of Environmental and Natural Resource Sciences, Faculty of Science and Technology, Universiti Kebangsaan Malaysia, 43600 UKM Bangi, Selangor, Malaysia.

E-mail: m.n.said@ukm.edu.my

Received date: 10 January 2018, Accepted date: 28 February 2018, Online date: 10 March 2018

Copyright: (c) 2018 Nik Norafida, N.A et al. This is an open-access article distributed under the terms of the Creative Commons Attribution License, which permits unrestricted use, distribution, and reproduction in any medium, provided the original author and source are credited.

\begin{abstract}
Environmental controls which are dependent on the soil are known as edaphic factors. Variations in soils supply as a medium in plant growth may lead to restrictions in the functioning and distribution of organisms and hence influence the structure of whole ecosystem. The edaphic essentials for plant growth are dependent on the physical and chemical characteristics of soils. A study was conducted at three "Kapur" forests in Peninsular Malaysia, to determine association between the tree communities and soil properties. Tree inventory and soil sampling were carried out in 30 plots $(50 \mathrm{~m} \times$ $20 \mathrm{~m}$ each) established within the three forests, namely, the Bukit Bauk Forest Reserve (BBFR) in Terengganu, Lesong Forest Reserve (LFR) in Pahang, and Kluang Forest Reserve (KFR) in Johor. All trees with diameter at breast height (dbh) of $5 \mathrm{~cm}$ and above were measured, tagged and identified, whilst soil samples were analysed for texture, $\mathrm{pH}$, base cations, available nutrients (that included of $\mathrm{Mg}, \mathrm{P}$ and $\mathrm{K}$ ) and inorganic nitrogen (ammonium- $\mathrm{N}$ and nitrate- $\mathrm{N}$ ).The most commonly occurring species came from the family Euphorbiaceae, followed by the families Myrtaceae and Lauraceae. Density-wise, Dipterocarpaceae and Dryobalanops aromatica recorded the highest density at family and species levels, respectively. The most important species based on the highest important value index ( $\left.I V_{i}\right)$ was Dryobalanops aromatica (Kapur) with index values of more than $15 \%$. Soil analyses showed that the soil texture was dominated by sandy clay loam, and the percentages organic matter content at all sites were low with mean percentages in the range of 4.69-6.06\%. In general, the soils of the study sites were acidic, whilst available nutrients occurred in the range of low to high concentrations. Canonical Correspondence Analysis (CCA) showed a low species-environment correlation. Nevertheless, the CCA species ordination diagram showed that several tree species appeared to be closely associated with soil factors such as $\mathrm{pH}$, inorganic nitrogen and available nutrients of $\mathrm{Mg}, \mathrm{K}$ and $\mathrm{P}$, thus, indicating the role of soil factors in influencing floristic distribution patterns of vegetation communities in the Kapur forest habitats.
\end{abstract}

Key words: soil factors; environmental gradient; floristic pattern; vegetation-environment relationships; mono-dominant forest

\section{INTRODUCTION}

Kapur dominated forests are named after the dominant species, Dryobalanops aromatica Gaertn.f., or Kapur as in the vernacular dialect. Dryobalanops aromatica is a very big, tall tree sometimes exceeding $65 \mathrm{~m}$ in height and $10 \mathrm{~m}$ in girth [1]. The tree species produces one of the major timbers wood in the Malaysian market with an excellent, medium-heavy, moderately durable constructional timber which is particularly resistant to fungal attack. This medium hard wood is suitable for heavy construction, in the making of poles, rafts, flooring, furniture, window panels, doors, staircases and railway sleepers [2].In Peninsular Malaysia, the Kapur forests are confined to two large blocks on the east coast (from the south of Terengganu to the north of Pahang and from the south of Pahang to the south, south east and east of Johor) and one block in two small pockets on the west coast of the Bukit Lagong and Kanching FRs [3].

Relationships between soil properties and plant species diversity of the tropical rainforest have been described since the 1990's by various researchers. At the Mulu National Park, Sarawak, [4] revealed the relationships of soil nutrients, floristics and habitats for plots in various alluvial forests, mixed dipterocarp, heath, and limestone forests. In the Lambir Hill National Park, Sarawak, two dipterocarp species, namely, Dipterocarpus globosus and Dryobalanops aromatica, showed strong relationship with soil $\mathrm{pH}(<5 \mathrm{pH})$ while another two species, Dryobalanops lanceolata and Hopea dryobalanoides, showed strong correlation with available phosphorus and the cations of $\mathrm{Ca}^{2+}$ and $\mathrm{Mg}^{2+}$ [5]. Several other studies had been carried out to look at relationships between tree communities and soil characteristics; for instance, [6] reported that Shorea curtisii was mainly found on ridges at hill forests where soils are infertile with low water holding capacity, and the species is also found in forests just above sea-level on coastal hills [7,8]. It was suggested that the distribution of $S$. curtisii is more strongly influenced by soil conditions than by the temperature regime $[6,9]$. 
Related studies at the peat swamp forests of Pahang in Peninsular Malaysia, which are immensely rich in the population of Gonystylus bancanus (Ramin melawis), a much sought-after timber, showed that the peat depth, soil $\mathrm{pH}$, total inorganic- $\mathrm{N}$, potassium, magnesium and phosphorus appeared to be the principal environmental determinants of tree communities in the study plots [10]. Nevertheless, [11] stated that the relationship of tree communities and soil properties in the study carried out at Tasik Chini, Pahang were weakly associated, but there were some species that were highly correlated with the soil chemical and organic matter content. The objective of the present study was to determine the tree community structure and its relationship with the edaphic factors at the Kapur forests of Peninsular Malaysia. The selected Kapur forests were Bukit Bauk Forest Reserve (BBFR), Terengganu; Lesong Forest Reserve (LFR), Pahang; and Kluang Forest Reserve (KFR), Johor (Figure 1). It is anticipated that the results from the study could provide significant information to the management authorities for conservation purposes.

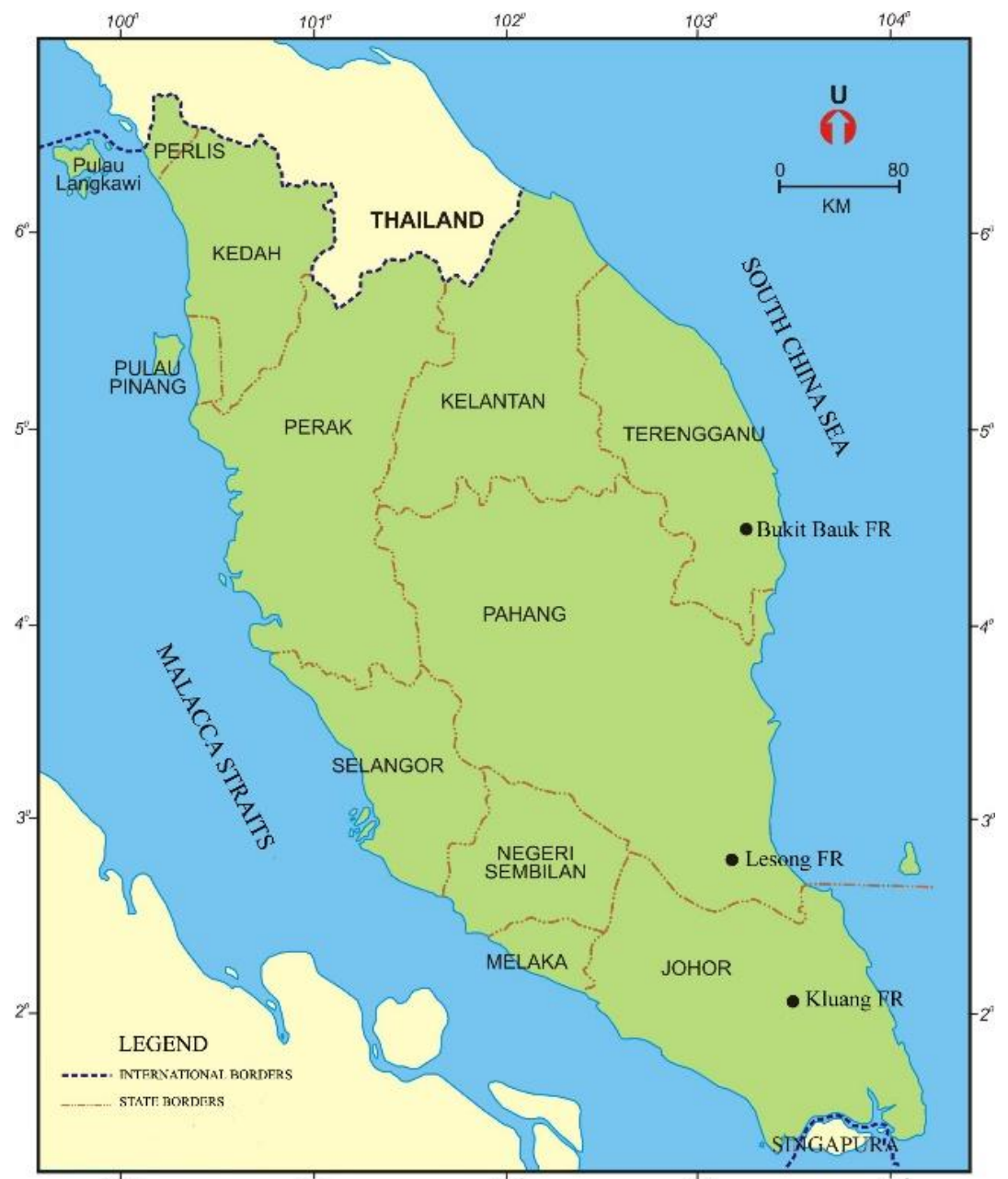

Fig. 1: Map of Peninsular Malaysia showing the location of the Bukit Bauk Forest Reserve (BBFR) in Terengganu, the Lesong Forest Reserve (LFR) in Pahang and the Kluang Forest Reserve (KFR) in Johor, Peninsular Malaysia

\section{MATERIALS AND METHODS}

Study plots and tree sampling:

A total of three study sites were selected. The first site was at the Bukit Bauk Forest Reserve (BBFR) in Terengganu, which is located at the south end of the East Coast Range that covers a total area of 7,596 ha. A one-hectare study plot (ten plots of $50 \mathrm{~m} \mathrm{x} 20 \mathrm{~m}$ each) was established at compartment 23 , which is $50 \mathrm{~m}$ above sea level (a.s.l), and positioned at latitude $4^{\circ} 45.834^{\prime} \mathrm{N}$ to $4^{\circ} 46.748^{\prime} \mathrm{N}$ and longitude $103^{\circ} 20.163^{\prime} \mathrm{E}$ to $103^{\circ} 20.474^{\prime} \mathrm{E}$. The second study site was at the Lesong Forest Reserve (LFR) in Pahang. It is the second largest forest reserve in Pahang with an area of 56,421 ha comprising 439 compartments, situated in the Rompin district, approximately $130 \mathrm{~km}$ from Kuantan, the capital of Pahang. Ten plots (50 m x $20 \mathrm{~m}$ each) were established at compartment 102 , which is $40 \mathrm{~m}$ above sea level (a.s.l), and positioned at latitude $2^{\circ} 49.164^{\prime} \mathrm{N}$ to $2^{\circ} 49.472^{\prime} \mathrm{N}$ and longitude $103^{\circ} 11.469^{\prime} \mathrm{E}$ to $103^{\circ} 11.953^{\prime}$ E. Finally, the third site at the Kluang Forest Reserve (KFR) covers a total study area of $30 \mathrm{ha}$, located in the state of Johor, $32 \mathrm{~km}$ from Kluang town. A one-hectare study plot that consisted of ten plots ( $50 \mathrm{~m} \mathrm{x} 20 \mathrm{~m}$ each) was established at compartment 129 , which is $90 \mathrm{~m}$ above sea level (a.s.l), and positioned at latitude $2^{\circ} 3.797^{\prime} \mathrm{N}$ to $2^{\circ} 4.151^{\prime} \mathrm{N}$ and longitude $103^{\circ} 31.545^{\prime} \mathrm{E}$ to $103^{\circ} 31.754^{\prime} \mathrm{E}$. In each plot, all trees measuring $5 \mathrm{~cm}$ diameter at breast height (DBH) and above were tagged and manually measured using the diameter tape at $1.3 \mathrm{~m}$ above the ground. Specimens of each measured tree were collected as voucher specimens for species identification, while tree identification was carried out using the reference text Tree Flora of Malaya $[12,13,14,15]$.

\section{Soil Analysis:}

In all 30 subplots, five topsoil samples from the depth of $0-20 \mathrm{~cm}$ were taken randomly within each subplot and the samples were then mixed together to represent the soil sample of the subplot. Particle size distribution was determined using the pipette method together with dry sieving. The texture of the soil was obtained by plotting the sand, silt and clay content in the triangle of texture. The organic matter (OM) content was determined by the "loss-on-ignition" method, igniting soils for $16 \mathrm{~h}$ at $400^{\circ} \mathrm{C}$ [16], while soil $\mathrm{pH}$ was measured using a pH meter in soil/water ratio of 1:2.5 [17]. The soils content was extracted with $1 \mathrm{M}$ potassium chloride $(\mathrm{KCl})$ for exchangeable acidic cations $\left(\mathrm{Al}^{+}\right)$, which were determined by titration. As for exchangeable base cations $\left(\mathrm{K}, \mathrm{Ca}^{2+}\right.$ and $\left.\mathrm{Mg}^{2+}\right), 1 \mathrm{M}$ ammonium acetate was used for the extraction and the extract was determined by flame atomic absorption spectrophotometry (FAAS). Available macronutrients and micronutrients in the soil were extracted using $1 \mathrm{M}$ ammonium acetate-acetic acid. The extract was run under the ultraviolet (UV) spectrophotometer for the determination of phosphorus, while the availability of potassium $(\mathrm{K})$, magnesium $(\mathrm{Mg})$, cuprum $(\mathrm{Cu})$, ferum $(\mathrm{Fe})$, manganese $(\mathrm{Mn})$ and zinc $(\mathrm{Zn})$ in the extracts were determined using the atomic absorption spectrophotometer (AAS). 
Data Analysis:

All trees enumerated in the study plots were summarized for overall floristic composition, and quantitative data were analyzed to determine species abundance. This included determination of basal area (BA), as well as calculation of the density and frequency of occurrence of each species. Frequency of occurrence indicated the number of plots in which a species occurred and was expressed as the proportion of the total number of plots taken in which the species in question was present [18], and the value was expressed as percentage. As for the BA, the parameter was calculated based on the equation from [19] as shown below:

$$
\begin{aligned}
\mathrm{BA}= & \frac{\pi \mathrm{D}^{2}}{4} \\
& \text { where } \pi=3.142 \\
& \mathrm{D}=\text { diameter at breast height }(\mathrm{cm})
\end{aligned}
$$

Importance value index $\left(I V_{i}\right)$ was calculated to determine species importance. The $I V_{i}$ was calculated by summing up the values of relative density $\left(R_{d}\right)$, relative dominance (based on basal area) $\left(R_{B}\right)$, and relative frequency $\left(R_{F}\right)$ of each species, and the sum was divided by three, which was expressed as percentage $\left[I V_{i}=\left(R_{d}+R_{B}+R_{F}\right) / 3\right][18]$.

Patterns of tree species composition in relation to the measured eight edaphic variables were analyzed using canonical correspondence analysis (CCA) [20] [21], which was performed using the CANOCO version 4.0 [22]. Prior to analysis, species with only one entry in the data matrix was deleted to increase the definition of the results. CCA is a constrained direct ordination technique wherein an 'optimal' solution is obtained by arranging sites and species in multidimensional space, with the restriction that the ordination axes must be linear combinations of the specified underlying environmental variables. The CCA output showed include a set of vectors that visually represent the strength and directionality of the relationship between the environmental variables and ordination axes. The parameters used in the analysis were species abundance and soil variables (soil $\mathrm{pH}$; available $\mathrm{P}, \mathrm{K}$ and $\mathrm{Mg}$; nitrate- $\mathrm{N}$ ammonium- $\mathrm{N}$; total cation exchange capacity $(\mathrm{CEC})$; calcium content $\left(\mathrm{Ca}^{2+}\right)$ ). The significance of each edaphic variable in determining the species compositional changes was assessed through the Monte Carlo permutation test based on 99 random trials at a 0.05 significance level [23].

\section{RESULTS AND DISCUSSION}

\section{General Characteristics of the Kapur Forest Tree Communities:}

A total of 4,135 trees were enumerated in all the 30 plots at all study areas. Floristic composition of these enumerated trees comprised 663 species from 203 genera and 63 families. At the Bukit Bauk FR (BBFR), 1,474 trees were censused with floristic composition of 336 species, 150 genera and 55 families. The Lesong FR (LFR) recorded 1,364 trees which contained 288 species, 138 genera and 52 families; and the Kluang FR (KFR) displayed a composition of 271 species, 132 genera and 52 families from 1,297 trees. In all sites, the largest family based on the highest number of species was indicated by the Euphorbiaceae, whilst the best represented genera at all sites was Syzygium (Table 1).

The results showed that all the study sites were mono-dominant forests dominated by the D. aromatica, whereby all abundance parameters of the tree communities were led by this species (Table 2). Dryobalanops aromatica was the most frequent species at all sites with frequency of $100 \%$, whereby it occurred in all plots. The species also showed the highest density in all the surveyed plots with the highest density was at the LFR of 266 stands/ha (Table 2). Moreover, the basal area (BA) of tree species clearly displayed $D$. aromatica as the highest BA in all study areas, and its basal areas were far higher than the species at second rank of each study area. Table 2 also showed the first five leading species based on $I V_{i}$, whereby $D$. aromatica was the most important species at all study sites with index values of more than $15 \%$. According to [24], species that exhibits $I V_{i}$ of more than $10 \%$, is considered as having absolute dominance in its community. Thus, this observation confirms the $D$. aromatica as the species of absolute dominant in all these Kapur forests.

\begin{tabular}{|c|c|c|c|c|}
\hline Study location & Family & No. Species & Genus & No. Species \\
\hline BBFR & Euphorbiaceae & 48 & Syzygium & 21 \\
\hline \multirow[t]{4}{*}{ (total species no. $=336$ species $)$} & Dipterocarpaceae & 27 & Shorea & 16 \\
\hline & Myrtaceae & 22 & Diospyros & 10 \\
\hline & Guttiferae & 19 & Aporosa & 9 \\
\hline & Annonaceae & 18 & Calophyllum & 9 \\
\hline LFR & Euphorbiaceae & 28 & Syzygium & 17 \\
\hline \multirow{4}{*}{ (total species no. $=288$ species $)$} & Annonaceae & 21 & Diospyros & 9 \\
\hline & Lauraceae & 20 & Calophyllum & 7 \\
\hline & Myrtaceae & 17 & Shorea & 7 \\
\hline & Guttiferae & 15 & Artocarpus & 6 \\
\hline KFR & Euphorbiaceae & 37 & Syzygium & 15 \\
\hline \multirow{4}{*}{ (total species no. $=271$ species $)$} & Dipterocarpaceae & 20 & Diospyros & 11 \\
\hline & Myrtaceae & 17 & Aporosa & 8 \\
\hline & Guttiferae & 15 & Shorea & 8 \\
\hline & Burseraceae & 14 & Garcinia & 6 \\
\hline
\end{tabular}

Table 1: Five leading families and genera based on the number of species in the Kapur forests at Bukit Bauk Forest Reserve (BBFR) in Terengganu, Lesong Forest Reserve (LFR) in Pahang and Kluang Forest Reserve (KFR) in Johor. 
Citation: Nik Norafida, N.A., Nizam, M.S., Wan Juliana, W.A. \& Faezah, P. 2018. Edaphic Relationships Among Tree Species in the Kapur (Dryobalanops aromatica Gaertn.f.) Forests of Peninsular Malaysia. Advances in Environmental Biology., 12(2): 11-16.

Table 2: Summary of abundance parameters of the five leading species in the 1-ha plots in the Kapur Forest at Bukit Bauk Forest Reserve (BBFR) in Terengganu, Lesong Forest Reserve (LFR) in Pahang, and Kluang Forest Reserve (KFR) in Johor. Species

\begin{tabular}{|c|c|c|c|c|}
\hline \multirow[b]{2}{*}{ Study Site } & \multicolumn{4}{|l|}{ Species } \\
\hline & $\begin{array}{l}\text { Density } \\
\text { (stands/ha) }\end{array}$ & $\begin{array}{l}\text { Frequency } \\
(\%)\end{array}$ & $\begin{array}{l}\text { Basal Area } \\
\left(\mathrm{m}^{2} / \mathrm{ha}\right)\end{array}$ & $\begin{array}{l}I V_{i} \\
(\%)\end{array}$ \\
\hline BBFR & $\begin{array}{l}\text { Dryobalanops aromatica (216) } \\
\text { Shorea macroptera }(28) \\
\text { Sarcotheca laxa var. sericea (26) } \\
\text { Gynotroches axillaris }(25) \\
\text { Saraca declinata }(23)\end{array}$ & $\begin{array}{l}\text { Dryobalanops aromatica }(100) \\
\text { Shorea macroptera }(90) \\
\text { Saraca declinata }(80) \\
\text { Paropsia vareciformis }(80) \\
\text { Gynotroches axillaris }(70)\end{array}$ & $\begin{array}{l}\text { Dryobalanops aromatica } \\
(17.28) \\
\text { Shorea macroptera }(1.33) \\
\text { Dipterocarpus lowii }(1.20) \\
\text { Shorea acuminata }(0.97) \\
\text { Dipterocarpus sublamellatus } \\
(0.83)\end{array}$ & $\begin{array}{l}\text { Dryobalanops aromatica } \\
(17.81) \\
\text { Shorea macroptera }(2.02) \\
\text { Saraca declinata }(1.26) \\
\text { Swintonia floribunda }(1.24) \\
\text { Shorea acuminata }(1.21)\end{array}$ \\
\hline LFR & $\begin{array}{l}\text { Dryobalanops aromatica (266) } \\
\text { Elateriospermum tapos }(62) \\
\text { Syzygium sp. }(29) \\
\text { Sapium baccatum (23) } \\
\text { Canarium littorale }(22)\end{array}$ & $\begin{array}{l}\text { Dryobalanops aromatica }(100) \\
\text { Elateriospermum tapos }(90) \\
\text { Knema patentinervia }(90) \\
\text { Sapium baccatum }(80) \\
\text { Sarcotheca laxa var. laxa }(80)\end{array}$ & $\begin{array}{l}\text { Dryobalanops aromatica } \\
(22.37) \\
\text { Elateriospermum tapos }(3.36) \\
\text { Syzygium sp. }(1.58) \\
\text { Cynometra malaccensis } \\
(1.00) \\
\text { Sapium baccatum }(0.80)\end{array}$ & $\begin{array}{l}\text { Dryobalanops aromatica } \\
\text { (23.01) } \\
\text { Elateriospermum tapos }(4.38) \\
\text { Syzygium sp. }(2.15) \\
\text { Cynometra malaccensis }(1.55) \\
\text { Sapium baccatum }(1.49)\end{array}$ \\
\hline KFR & $\begin{array}{l}\text { Dryobalanops aromatica }(110) \\
\text { Hopea dyeri }(80) \\
\text { Fordia johorensis }(54) \\
\text { Dillenia albiflos }(48) \\
\text { Elateriospermum tapos }(37)\end{array}$ & $\begin{array}{l}\text { Dryobalanops aromatica }(100) \\
\text { Elateriospermum tapos }(90) \\
\text { Fordia johorensis }(90) \\
\text { Hopea dyeri }(80) \\
\text { Dillenia albiflos }(80)\end{array}$ & $\begin{array}{l}\text { Dryobalanops aromatica } \\
(15.23) \\
\text { Dipterocarpus lowii }(2.90) \\
\text { Elateriospermum tapos }(1.58) \\
\text { Shorea pauciflora }(1.06) \\
\text { Dialium platysepalum }(0.68)\end{array}$ & $\begin{array}{l}\text { Dryobalanops aromatica } \\
(16.25) \\
\text { Hopea dyeri (3.04) } \\
\text { Dipterocarpus lowii }(2.91) \\
\text { Elateriospermum tapos }(2.78) \\
\text { Dillenia albiflos }(2.20)\end{array}$ \\
\hline
\end{tabular}

\section{General Soil Characteristics:}

In general, soil samples taken from all the 30 subplots were of sandy loam texture with high mean sand content at all sites (Table 3 ). Soil pH of the study plots showed low $\mathrm{pH}$ values with range mean values of 3.77 to 4.30 , and no significant different of $\mathrm{pH}$ values between sites. The acidic soil found in the area was in line with the findings of [25] where it was mentioned that most soils in the tropical rain forests of Peninsular Malaysia were acidic with pH values between 3.5 and 5.5. Furthermore, [26] reported that most general-purpose bacteria and actinomycetes function well at intermediate to high pH values. In earlier studies, [27] and [11] also reported that the soil pH was acidic with values ranging from $3.44-4.09$ at the Pasoh Forest Reserve in Negeri Sembilan and Chini Forest Reserve in Pahang. In terms of organic matter content, the soil in the study areas indicated mean percentage organic matter of between 4-6\%, which indicated low organic matter content. The soils that support the vegetation of tropical rain forests contain a relatively low amount of organic matter [28]. This is due to the rapid decomposition of plant litter in the ecosystem.

The cation exchange capacity (CEC) of the soils in the study areas showed the highest mean value at the BBFR of $7.25 \pm 0.70 \mathrm{meq} / 100 \mathrm{~g}$, nevertheless no significant different of mean CEC concentration between sites. The CEC depends on $\mathrm{pH}$ values and is lower in acidic conditions [6]. Previous study reported a low CEC value of $9.48 \mathrm{meq} / 100 \mathrm{~g}$ for the Pasoh Forest Reserve [27], whilst in Tasik Chini Forest Reserve, Pahang, mean values of $7.94 \mathrm{meq} / 100 \mathrm{~g}$ was recorded for the inland forest, $8.34 \mathrm{meq} / 100 \mathrm{~g}$ for the seasonal flooded forest and $9.01 \mathrm{meg} / 100 \mathrm{~g}$ for the riverine forest [11]. The low values of CEC recorded in the above studies indicated that the concentration of salt in the soils is low and it does not restrict the intake of water by plants [29].

The mean values of available phosphorus $(\mathrm{P})$, magnesium $(\mathrm{Mg})$ and potassium $(\mathrm{K})$ were varied between sites. Inorganic nitrogen in the forms of nitrate- $\mathrm{N}$ $\left(\mathrm{NO}_{3}-\mathrm{N}\right)$ and ammonium-N $\left(\mathrm{NH}_{4}-\mathrm{N}\right)$, which are among the important macronutrients for plant growth were also determined; mean concentrations of $\mathrm{NO}_{3}-\mathrm{N}$ differed significantly between forest locations, but no significant different of $\mathrm{NH}_{4}-\mathrm{N}$ concentrations between sites. A previous study by [27] showed that the inorganic N pool at the Pasoh FR was $5.08 \pm 0.45 \mu \mathrm{g} / \mathrm{g}$ for ammonium-N, and $3.50 \pm 0.32 \mu \mathrm{g} / \mathrm{g}$ for nitrate-N. Maximum growth rates and plant yields are obtained by a combined supply of both $\mathrm{NH}_{4}^{+}$and $\mathrm{NO}_{3}^{-}$. When both $\mathrm{NH}_{4}^{+}$and $\mathrm{NO}_{3}^{-}$are supplied, optimal pH value may be achieved by similar rates of $\mathrm{H}^{+}$production $\left(\mathrm{NH}_{4}{ }^{+}\right.$assimilation) and $\mathrm{H}^{+}$consumption $\left(\mathrm{NO}_{3}{ }^{-}\right.$assimilation) with very low energy requirement [26, 30]. This may, at least, partially explain that optimal growth for most plant species is usually obtained with a mixture of both $\mathrm{NH}_{4}^{+}$and $\mathrm{NO}_{3}^{-}$.

Table 3: Summary of soil variables of the Kapur forests at Bukit Bauk Forest Reserve (BBFR) in Terengganu, Lesong Forest Reserve (LFR) in Pahang and Kluang Forest Reserve (KFR) in Johor. Superscript of different alphabets denote significance values between sites ( $<<0.05 ; t$-test)

\begin{tabular}{|c|c|c|c|}
\hline Soil Parameter & BBFR & LFR & KFR \\
\hline $\mathrm{pH}$ & $3.77 \pm 0.04^{\mathrm{a}}$ & $4.30 \pm 0.04^{\mathrm{a}}$ & $3.95 \pm 0.05^{\mathrm{a}}$ \\
\hline$\%$ Organic Matter Content & $6.06 \pm 0.57^{\mathrm{a}}$ & $4.70 \pm 0.45^{\mathrm{b}}$ & $4.69 \pm 0.25^{\mathrm{ab}}$ \\
\hline Cation exchange capacity (CEC) (meq/100g) & $7.25 \pm 0.70^{\mathrm{a}}$ & $5.29 \pm 0.46^{\mathrm{a}}$ & $5.92 \pm 0.94^{\mathrm{a}}$ \\
\hline $\mathrm{Ca}^{2+}(\mathrm{meq} / 100 \mathrm{~g})$ & $0.22 \pm 0.02^{\mathrm{a}}$ & $0.24 \pm 0.02^{\mathrm{a}}$ & $0.36 \pm 0.04^{\mathrm{b}}$ \\
\hline $\mathrm{Na}^{+}(\mathrm{meq} / 100 \mathrm{~g})$ & $0.27 \pm 0.01^{\mathrm{a}}$ & $0.04 \pm 0.01^{\mathrm{b}}$ & $0.23 \pm 0.01^{\mathrm{c}}$ \\
\hline Available $\mathrm{Mg}(\mu \mathrm{g} / \mathrm{g})$ & $46.66 \pm 4.62^{\mathrm{a}}$ & $65.38 \pm 15.77^{\mathrm{a}}$ & $51.88 \pm 7.00^{\mathrm{a}}$ \\
\hline Available K $(\mu \mathrm{g} / \mathrm{g})$ & $86.36 \pm 7.96^{\mathrm{a}}$ & $12.74 \pm 4.07^{\mathrm{b}}$ & $101.57 \pm 10.60^{\mathrm{ac}}$ \\
\hline Available $\mathrm{P}(\mu \mathrm{g} / \mathrm{g})$ & $8.63 \pm 0.41^{\mathrm{a}}$ & $5.49 \pm 0.15^{\mathrm{b}}$ & $8.64 \pm 0.38^{\mathrm{ac}}$ \\
\hline Nitrate- $N(\mu \mathrm{g} / \mathrm{g})$ & $13.00 \pm 1.63^{\mathrm{a}}$ & $4.60 \pm 0.68^{\mathrm{b}}$ & $2.40 \pm 0.21^{\mathrm{c}}$ \\
\hline Ammonium-N( $\mu \mathrm{g} / \mathrm{g})$ & $17.23 \pm 2.09^{\mathrm{a}}$ & $13.77 \pm 1.28^{\mathrm{a}}$ & $15.03 \pm 2.14^{\mathrm{a}}$ \\
\hline silt $(\%)$ & $36.36 \pm 2.93^{\mathrm{a}}$ & $23.71 \pm 2.52^{b}$ & $21.42 \pm 3.96^{\mathrm{bc}}$ \\
\hline clay $(\%)$ & $23.84 \pm 1.82^{\mathrm{a}}$ & $19.86 \pm 1.54^{\mathrm{a}}$ & $22.44 \pm 2.25^{\mathrm{a}}$ \\
\hline sand $(\%)$ & $39.81 \pm 2.74^{\mathrm{a}}$ & $56.43 \pm 3.32^{\mathrm{b}}$ & $56.14 \pm 5.76^{\mathrm{b}}$ \\
\hline
\end{tabular}

Soil-vegetation Relationships:

The output of vegetation and soil data at the study site were summarized in Table 4 . The species-environment correlations were high at all axes, with first and second axes indicate correlation values of 0.988 and 0.974 , respectively. The eigenvalues of first axis is 0.579 and 0.460 for the second axis. There were significant relationships between tree species distribution and soil factors $(\mathrm{p}=0.002)$ based on the Monte-Carlo permutation test. The first three axes indicate a cumulative species-environment correlation of 58.9\%. From the CCA output, the ordination by CCA on the 30 study plots is shown in Figure 2 . Direct ordination of CCA examines the similarity or dissimilarity of the floristic composition of vegetation samples, whereby the distances between the points on the graph are taken as a measurement of their degree of similarity or difference. Points that are close together will represent subplots that are similar in species composition, whilst the 
further apart any two points are the more dissimilar or different the plots will be. From Figure 2, the plots were reasonably separated floristically in the ordination space of the axes, showing that the plots that are floristically similar were closer to each other. From the diagram, it is clear that the soil differences varied between each plot as they were separated, and that there was a soil gradient in relation to tree species composition of the different plots.

Table 4: Summary of CCA output on vegetation and soil data at the Bukit Bauk Forest Reserve (BBFR) in Terengganu, Lesong Forest Reserve (LFR) in Pahang and Kluang Forest Reserve (KFR) in Johor.

\begin{tabular}{|c|c|c|c|c|c|}
\hline & & & & & Total Inertia \\
\hline Axes & 1 & 2 & 3 & 4 & \\
\hline Eigenvalues & 0.579 & 0.460 & 0.300 & 0.277 & 8.075 \\
\hline Species-environment correlations & 0.988 & 0.974 & 0.970 & 0.982 & \\
\hline \multicolumn{6}{|l|}{ Cumulative percentage variance } \\
\hline of species data & 7.2 & 12.9 & 16.6 & 20.0 & \\
\hline of species-environment relation & 25.5 & 45.7 & 58.9 & 71.1 & \\
\hline Sum of all eigenvalues & & & & & 8.075 \\
\hline Sum of all canonical eigenvalues & & & & & 2.272 \\
\hline
\end{tabular}

The CCA biplot showed that a strong influence of the soil vectors could be seen for each plot, whereby tree species composition of plots at the Bukit Bauk Forest Reserve (BBFR) were strongly influenced by $\mathrm{NH}_{4}-\mathrm{N}$ and $\mathrm{NO}_{3}-\mathrm{N}$, whilst plots at the Kluang Forest Reserve (KFR) were closely associated with Ca ${ }^{2+}$, and plots at the Lesong Forest Reserve (LFR) were influenced by the soil pH. Results of the CCA are congruent with previous observations [5] and clearly indicated the strong influence of inorganic nitrogen, $\mathrm{Ca}^{2+}$ and soil $\mathrm{pH}$. Available inorganic nitrogen in the forest soil is needed for plant growth and survival [26]. The CEC which involves hydrogen $\left(\mathrm{H}^{+}\right)$, aluminium $\left(\mathrm{Al}^{3+}\right)$, calcium $\left(\mathrm{Ca}^{2+}\right)$, magnesium $\left(\mathrm{Mg}^{2+}\right)$, potassium $\left(\mathrm{K}^{+}\right)$and sodium $\left(\mathrm{Na}^{+}\right)$is used to measure fertility, nutrient retention capacity, and the capacity to protect groundwater from cation contamination [26].

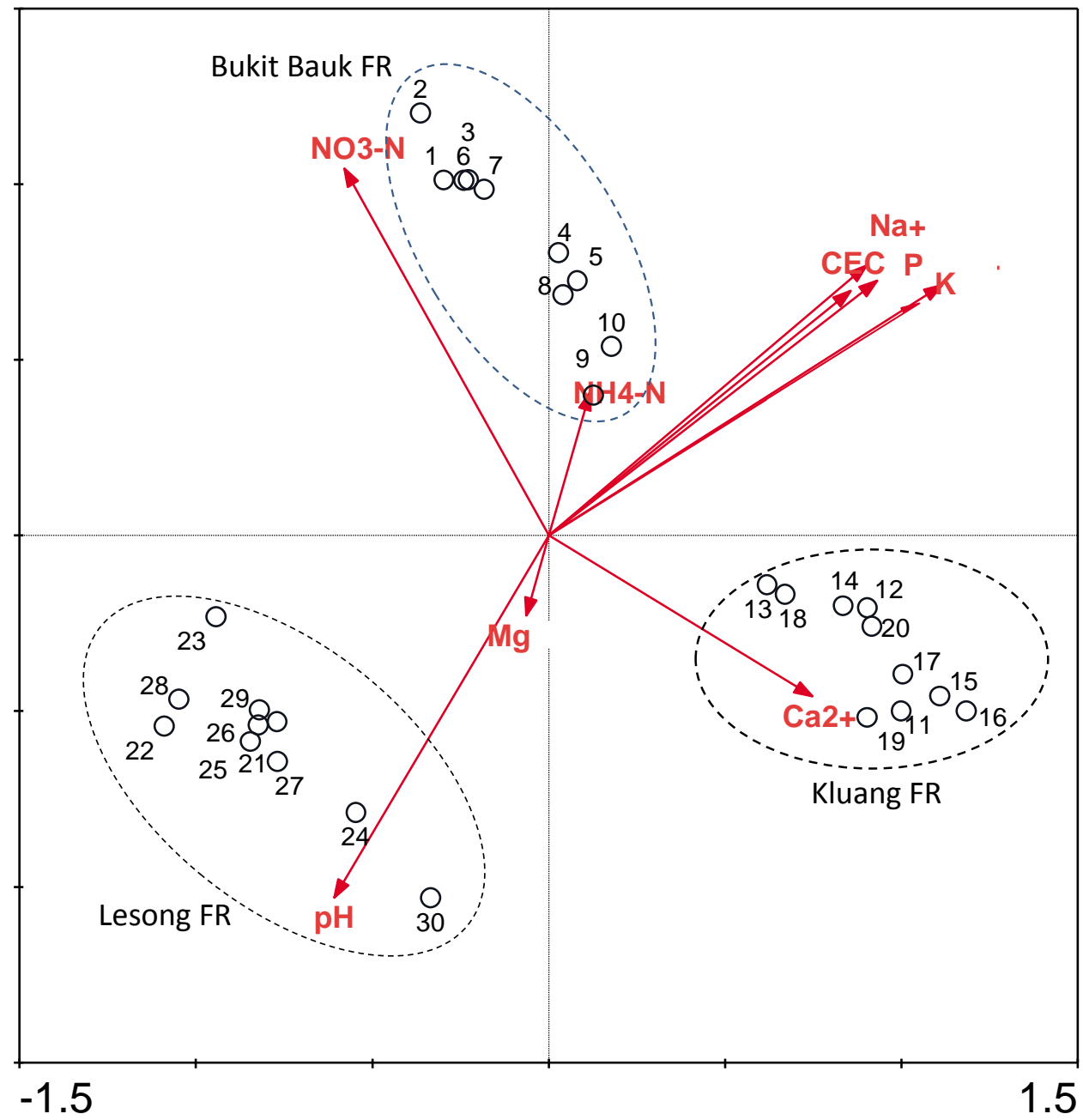

Fig. 2: Canonical correspondence analysis (CCA) ordination plot showing the approximate location of sample plots and locations, lengths and directions of soil variables. Plots 1-10 = Bukit Bauk Forest Reserve (BBFR), Plots 11-20 = Kluang Forest Reserve (KFR); Plots 21-30 = Lesong Forest Reserve (LFR); Legend: $\mathrm{pH}=$ soil $\mathrm{pH} ; \mathrm{Mg}=$ available $\mathrm{Mg} ; \mathrm{P}=$ available phosphorus; $\mathrm{K}=$ available potassium; $\mathrm{CEC}=$ total cation $^{\text {exchange }}$ capacity; $\mathrm{Ca}^{2+}=$ ion calcium; $\mathrm{NH} 4-\mathrm{N}=$ ammonium-N; NO3-N= nitrate-N

\section{Conclusion:}

In conclusion, the forest communities at all Kapur forests were dominated by one species, i.e. Dryobalanops aromatica, which was the important tree species in these forests. Although the D. aromatica was the dominant species at all three sites, nevertheless the tree species composition was strikingly different between sites. The differences of species composition between the sites were well explained by the edaphic factors illustrated via the species-environment relationship produced by the CCA. Conservation of mono-dominant forest should take into consideration the habitat characteristic, i.e. the soil properties, because tree-soil relationship has been proven as one of the important factor that influence the tree species distribution in such forests. 


\section{ACKNOWLEDGEMENTS}

The authors would like to thank the Forestry Department of Terengganu, Pahang and Johor for allowing access to the study sites and assistance on the ground. We are also grateful to the late Sani Miran and Ahmad Fitri Zohari for helping in the field work and plant identification, and Prof. Dr. Ismail Sahid for his invaluable contributions in the preparation of this manuscript; the Universiti Kebangsaan Malaysia Research University Grant GUP-2013-056 and DPP-2013-184 for the funding granted throughout the study.

\section{REFERENCES}

[1] Ashton, P.S., 1982. Dipterocarpaceae. Flora Malesiana, Series I, 9(2): 237-552.

[2] Ser, C.S., 1981. Malaysian timbers-Kapur. Timber Trade Leaflet No. 46. The Malaysian Timber Industry Board and Forest Research Institute Malaysia, Kuala Lumpur.

[3] Wyatt-Smith, J., 1964. Manual of Malayan silviculture for inland forests. Malayan Forest Records, p: 23.

[4] Newbery, D.M and J. Proctor, 1984. Ecological studies in four contrasting lowland rain forests in Gunung Mulu National Park, Sarawak. IV. Associations between tree distribution and soil factors. Journal of Ecology, 72: 475-493.

[5] Davies, S.J, S. Tan, J.V. La Frankie and M. Potts, 2005. Soil-related floristic variation in a hyperdiverse dipterocarp forest. In: Pollination ecology and the rain forest, Roubik, D.W., Sakai, S. and Hamid Karim, A.A. (Eds.), pp: 22-34. Springer Berlin.

[6] Whitmore, T.C., 1984. Tropical Rain Forests of the Far East, Second edition. Oxford University Press London.

[7] La Frankie, J.V., S.J. Davies, L.K. Wang, S.K. Lee and S.K.Y. Lum, 2005. Forest Trees of Bukit Timah: population ecology in a tropical forest fragment. Simply Green Singapore.

[8] Tam, S.M., 1999. Floristic diversity of Bukit Bauk (Terengganu), Peninsular Malaysia. Garden Bulletin of Singapore, 51: $257-308$.

[9] Burslem, D.F.R.P., I.M. Turner and G.J. Grubb, 1994. Mineral nutrient status of coastal hill dipterocarp forest and Adinandra belukar in Singapore: bioassay nutrient limitation. Journal of Tropical Ecology, 10: 579-599.

[10] Nizam, M.S., P. Ismail, A. Latiff, I. Shamsudin and I. Faridah-Hanum, 2009. Diversity of tree communities and its relationships with soil properties in a peat swamp forest in Pahang, Peninsular Malaysia. Ecology Environment and Conservation, 15(2): 3017-318.

[11] Khairil, M., W.A. Wan Juliana and M.S. Mohd Nizam, 2014. Edaphic influences on tree species composition and community structure in a tropical watershed forest in Peninsular Malaysia. Journal of Tropical Forest Science., 26(2): 284-294.

[12] Whitmore, T.C., 1972. Tree Flora of Malaya, Vol 1. Longman Kuala Lumpur.

[13] Whitmore, T.C., 1973. Tree Flora of Malaya, Vol 2. Longman Kuala Lumpur.

[14] Ng, F.S.P., (ed.). 1978. Tree Flora of Malaya, Vol. III. Longman Kuala Lumpur.

[15] Ng, F.S.P. (ed.). 1989. Tree Flora of Malaya, Vol. IV. Longman Kuala Lumpur.

[16] Avery, B.W. and C.L. Bascomb, 1982. Soil survey laboratory methods. Soil Survey Technical Monograph No. 6 Harpenden.

[17] Metson, A.J., 1956. Methods of chemical analysis for soil survey samples. New Zealand Soil Bureau Bulletin 12. New Zealand

[18] Brower, S.E., J.H. Zar and C.N. Ende, 1997. Field and Laboratory Methods for General Ecology4th ed. Mc Graw Hill, Boston.

[19] Husch, B.M., T.W. Beers and J.A. Kershaw Jr., 2003. Forest mensuration. $4^{\text {th }}$ ed. New York: John Wiley \& Sons.

[20] Ter Braak, C.J.F. and E.C. Prentice, 1988. A theory of gradient analysis. Advances in Ecological Research, 18: $271-317$.

[21] Ter Braak, C.J.F., 1992. CANOCO-A FORTRAN program for canonical communities ordination. Microcomputer Power, Ithaca, New York.

[22] Ter Braak, C.J.F and P. Šmilauer, 1998. CANOCO Reference Manual and User's Guide to Canoco for Windows: Software for Canonical Community Ordination, Version 4. Microcomputer Power, Ithaca, New York.

[23] Ter Braak, C.J.F., 1999. Update notes: CANOCO, Version 3.10. Agricultural Mathematics Group, Wagenigen.

[24] Curtis, J.T. and R.P. Macintosh, 1951. An upland continuum in the prairie-forest forder region of Wisconsin. Ecology, 32: $476-496$.

[25] Othman, Y and J. Shamshuddin, 1982. Sains Tanah. Dewan Bahasa dan Pustaka, Kuala Lumpur.

[26] Brady, N.C. and R.R. Weil, 1996. The Nature and Properties of Soils. $11^{\text {th }}$ ed. Prentice-Hall Inc., New Jersey.

[27] Nurfazliza, K., M.S. Nizam and M.N. Nur Supardi, 2012. Association of liana communities with their soil properties in a lowland forest of Negeri Sembilan, Peninsular Malaysia. Sains Malaysiana, 41(6): 679-690.

[28] Wood, M., 1989. Soil Biology. Chapman \& Hall, New York.

[29] London, J.R., 1991. Booker Tropical Soil Manual: a Handbook for Soil Survey and Agricultural Land Evaluation in the Tropics and Subtropics. Longman, London and New York.

[30] Ismail, A. and M.J. Yaakob, 1994. Tumbuh-tumbuhan dan Persekitaran: Satu Perspektif Geografi. Dewan Bahasa dan Pustaka, Kuala Lumpur. 